\title{
Botanical (morphological, micrographic), chemical and pharmacological characteristics of Pfaffia species (Amaranthaceae) native to South Brazil
}

\author{
Grace Gosmann', Susana Gattuso², Martha Gattuso², Raquel Fenner', Elyara Fiorin Pacheco', \\ Alexandre Ferraz ${ }^{1,3}$, Luciane Anita Savi ${ }^{4}$, Célia Regina Monte Barardi ${ }^{5}$, \\ Cláudia Maria Oliveira Simões ${ }^{4}$, Maximiliano Sortino², Susana Zacchino², \\ Carmela Gnerre $^{6}$, Bernard Testa ${ }^{6}$, Stela Maris Kuze Rates ${ }^{1 *}$
}

${ }^{1}$ Faculdade de Farmácia, Universidade Federal do Rio Grande do Sul ,UFRGS, ${ }^{2}$ Facultad de Ciencias Bioquímicas y Farmacéuticas, Universidad Nacional de Rosario, Rosario, Argentina, ${ }^{3}$ Centro Integrado do Câncer, Universidade Luterana do Brasil, Canoas, RS, ${ }^{4}$ Laboratório de Virologia Aplicada, Departmento de Ciências Farmacêuticas (CCS), Universidade Federal de Santa Catarina, ${ }^{5}$ Departamento de Microbiologia e Parasitologia (CCB), Universidade Federal de Santa Catarina, 'Institute de Chimie Thérapeutique Section de Pharmacie, Université de Lausanne, Lausanne-Dorigny, Switzerland

*Correspondence:

S. M. K. Rates

Faculdade de Farmácia

Universidade Federal do Rio Grande do Sul

Av. Ipiranga 2752, 90610-000

Porto Alegre, RS, Brazil

E-mail: ratessmk@farmacia.ufrgs.br
Some parameters for the quality control of $\mathrm{P}$. glomerata and $\mathrm{P}$. paniculata roots using their botanical and chemical characteristics are presented. It was also carried out an in vitro pharmacological screening to evaluate some biological properties of P. glomerata that could be related to its popular use as "tonic". Relating to biological assays, ethanolic extract from P. glomerata roots did not present antiviral, antiproliferative, antifungal or MAO inhibitory activities. The cytotoxicity evaluation of $\mathrm{P}$. glomerata determined that $I C_{50}$ is $>2,000 \mu \mathrm{g} / \mathrm{mL}$. The main morphological and micrographic characteristics of $\mathrm{P}$. glomerata and $\mathrm{P}$. paniculata roots are described in this paper in order to aid in their unequivocal identification.
UNITERMS:

- Pfaffia glomerata

- Pfaffia paniculata

- Brazilian ginseng

- Micrography

- Quality control

\section{INTRODUCTION}

Around ninety species of Pfaffia (Amaranthaceae) are known in Central and South America, twenty-seven species have been described in Brazil (Vasconcelos, 1982; Taniguchi et al., 1997). They are popularly known as "corango", "suma", "paratudo" and "Brazilian ginseng" since Pfaffia species are commonly used for the same therapeutic indications as ginseng (Panax spp. Araliaceae) (Oliveira, 1986). Although P. paniculata is the most employed in commercial preparations in Brazil, $P$. glomerata is commonly used in the State of Rio Grande do Sul (South of Brazil) labeled either as P. glomerata or wrongly as $P$. paniculata. A study of the differences between these two latter species is clearly needed in order to avoid adulterations that could result in undesirable or toxic effects.

Regarding chemical constituents from roots of Pfaffia species, allantoin, ecdysteroids, pfaffic acid and their glycosides (nortriterpene saponins), stigmasterol and sitosterol (Nakai et al., 1984; Nishimoto et al., 1984, 1988; Shiobara et al., 1993 a,b; Takemoto et al., 1983) have been identified.

Earlier pharmacological studies showed that ethanolic extract of $P$. glomerata roots possessed central nervous depressant activity (De Paris et al., 1998b, 2000) 
while crude extracts from P. paniculata displayed antiinflammatory, sexual stimulant activities and low toxicity in rodents (Mazzanti, Braghirolli, 1994; Arletti et al., 1999). In turn, triterpene saponins from P. paniculata showed to possess antitumoural activity (Nishimoto et al., 1984).

In particular, one of the aims of this work is to provide botanical parameters for the quality control of $P$. glomerata and $P$. paniculata. In part due to difficult botanical differentiation among Pfaffia species, it is quite common the misidentification of the raw material in commercial preparations (Santos et al., 1987; De-Paris et al., 1998a). The major morphological features and the micrographic characters of $P$. glomerata and $P$. paniculata roots are presented here in order to give the necessary background for their unequivocal identification.

In addition, we discuss the thin-layer chromatography (TLC) profile of $P$. glomerata and $P$. paniculata species, and the antifungal, antiproliferative, antiviral, MAO inhibitory activities and cytotoxic properties of $P$. glomerata roots. These data could be relevant for future assesment of efficacy and safe use of $P$. glomerata in the traditional medicine of South Brazil.

\section{MATERIALS AND METHODS}

\section{Plant Material}

Pfaffia glomerata (Spreng.) Pedersen and Pfaffia paniculata (Mart.) O. Kuntze fresh roots were obtained from the cultivated area of the Centro Pluridisciplinar de Pesquisas Químicas, Biológicas e Agrícolas (CPQBA), UNICAMP, Campinas, São Paulo, Brazil. For botanical characterization, the roots were collected on October 1999 by one of the authors (S.J.G.) and voucher specimens ( $P$. glomerata Gattuso 754, P. paniculata Gattuso 755) are kept in both, U.N.R. Herbarium and in the Herbarium of the Vegetal Biological Area, of National University of Rosario, Argentina. For chemical and biological analysis, the roots were collected and identified at CPQBA on January 2000 by Ílio Montanari (P. glomerata, CPQBA 0238, P. paniculata, CPQBA 0241).

\section{Extraction Procedures}

Roots and rhizomes (subterraneous parts) from $P$. glomerata and P. paniculata were reduced to small pieces, dried in circulating air stove $\left(45^{\circ} \mathrm{C}\right)$ and triturated. The powder was extracted with $60 \%$ ethanol under reflux (1:10, plant:solvent, w/v) during 6 hours. The ethanol was removed under "vacuum" and the resulting residue was lyophilized and stored under light protection. The yield of both lyophilized extracts was $28 \%$ in relation to the dried subterraneous parts.

\section{Micrographic Studies}

Fresh and fixed (formaldehyde: ethanol:acetic acid:water, 2:10:1:3.5) roots from both species were used. Longitudinal and transverse sections of the roots measuring $10 \mu \mathrm{m}$ were prepared with microtome and stained with Safranin and Fast Green (Dizeo de Strittmater, 1979). Sections were mounted in synthetic balsam. Roots was macerated by conventional methods (Boodle, 1916). The distributions of calcium oxalate crystals was visualized by a polarizing microscope. Original drawings were made with a drawing device. Symbols proposed by Metcalfe and Chalk (1957) were used in the diagrams. The black and white photomicrographs were performed with the Axiolab Zeiss Automatic System.

\section{TLC Analyses}

TLC was carried out on silica gel (Merck, $\left.\mathrm{GF}_{254}\right)$ using either chloroform:ethanol $(95: 5, \mathrm{v} / \mathrm{v})$ or butanol:ethyl acetate:water:acetic acid $(4: 1: 5: 1, \mathrm{v} / \mathrm{v})$. Compounds were visualized by heating $\left(120^{\circ} \mathrm{C}\right)$ using the anisaldehyde-sulfuric acid-sprayed plates. Ecdysterone, oleanolic acid, sitosterol and stigmasterol were used as authentic samples.

\section{Antiviral Activity of $\boldsymbol{P}$. glomerata}

Ethanolic extract was evaluated for cytotoxicity, antiviral and virucidal action according to Simões et al. (1999), using VERO cells (ATCC:CCL81) and Herpes simplex virus type 1 (HSV-1)/strains VR733 (ATCC), KOS and 29R/acyclovir resistant (Laboratoire de Pharmacognosie, Faculté de Pharmacie, Université de Rennes I, Rennes, France). To assess the effects of the extract, dilutions ranging from 2,000 to $1.9 \mathrm{mg} / \mathrm{mL}$ were prepared in 199 media.

\section{Antiproliferative Activity of $\boldsymbol{P}$. glomerata}

This test was performed following the methodology described elsewhere (Likhitwitayawuid et al., 1993). The ethanolic extract was dissolved (serial dilutions ranging from 5 to $1000 \mu \mathrm{g} / \mathrm{mL}$ ) in DMSO and added to the cell culture medium to give a final concentration of co-solvent of $0.1 \%(\mathrm{v} / \mathrm{v})$. The following cell culture systems were used: A-375 human malignant melanoma, A-549 human non-small cell lung carcinoma, WiDr human colon carci- 
noma, from the American Type Culture Collection (Rockville; MD, USA).

\section{Antifungal Assays of $\boldsymbol{P}$. glomerata}

The fungistatic activity was evaluated by the agar dilution method using Sabouraud-chloramphenicol agar for yeast, filamentous fungi and dermatophytes, according to reported procedures (Mitscher et al., 1972; Zacchino et al., 1998, 1999; Feresin et al., 2001). The following strains were used: Candida albicans ATCC 10231, Candida tropicalis C 131, Saccharomyces cerevisiae ATCC 9763, Cryptococcus neoformans ATCC 32264, Aspergillus flavus ATCC 9170, Aspergillus fumigatus ATTC 26934 and Aspergillus niger ATCC 9029. Dermatophytes: Microsporum canis C 112, Trichophyton rubrum C 110, T. mentagrophytes ATTC 9972, Epidermophyton floccosum C 114 and Microsporum gypseum C 115 kindly provided by CEREMIC, Centro de Referencia Micológica, Facultad de Ciencias Bioquímicas y Farmacéuticas, Suipacha 531, Rosario, Argentina. The extract was solubilized in DMSO and added to the culture medium to give a final concentration that does not exceed $2 \%(\mathrm{v} / \mathrm{v})$ to give serial decreasing dilutions ranging from 1000 to $250 \mu \mathrm{g} / \mathrm{mL}$.

\section{MAO Inhibitory Activity of $\boldsymbol{P}$. glomerata}

The ethanolic extract was assayed for monoamine oxidase $\mathrm{A}$ (MAO A) and MAO B inhibitory activity in rat brain mitochondrial preparations at concentrations ranging from 1 to $20 \mathrm{mg} / \mathrm{mL}$, following the methodology described by Gnerre et al. (2001). The extract was dissolved in DMSO and added to the cell culture medium to give a final concentration of co-solvent of $5 \%(\mathrm{v} / \mathrm{v})$.

\section{RESULTS AND DISCUSSION}

\section{Morphological and micrographic analyses of roots from Pfaffia glomerata (Spreng) Pedersen and Pfaffia paniculata (Mart.) O. Kuntze}

Morphological and micrographic descriptions of the main characteristics of these plants are necessary to provide unique insights into unequivocal recognition of $P$. glomerata and P. paniculata.

\section{Common characteristics of the roots}

Both species consist of underground swollen roots, the outer surface is yellow-brown to brown and transversely rugose. The transverse root sections show a narrow bark composed of almost tabulated phellem cells. The anatomical peculiarity is the anomalous growth in thickness, which takes place by the development of a succession of collateral vascular bundles from rings of secondary meristematic tissue. The secondary bundles are embedded in conjunctive parenchyma. Subsequently, the accessory cambium arises from parenchyma cells on the periphery of the phloem of each vascular bundle. The secondary phloem was composed of sieve tube elements, companion cells, and axial parenchyma. The secondary xylem was composed of vessel, tracheids, xylem fibres and axial parenchyma (Figure 1).

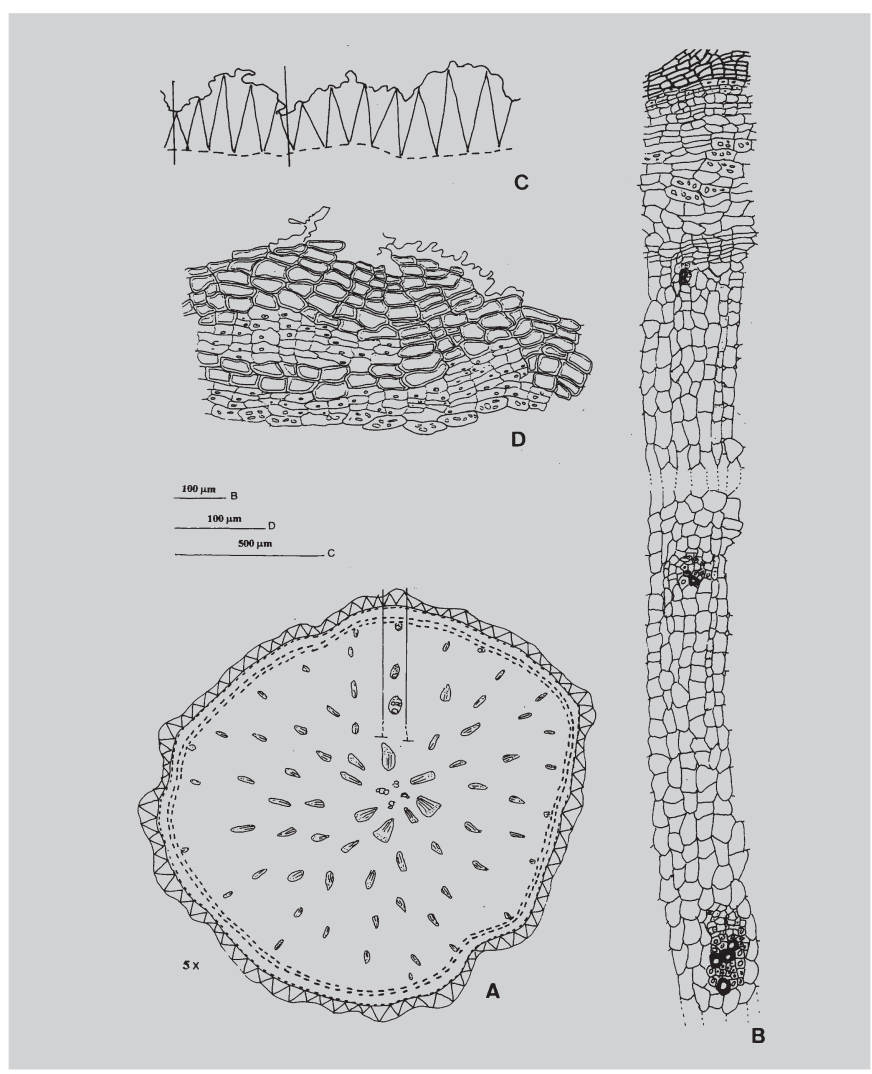

FIGURE 1 - A-D Common characteristes of Pfaffia Mart. A: Metcalfe \& Chalk' root diagram; B: detail of A; C: Metcalfe \& Chalk'bark diagram; D: detail of C.

\section{Non-common characteristics of the roots}

Comparisons of non-common characteristics of the roots are summarized in Table I. Detailed descriptions are presented below.

\section{Pfaffia glomerata}

The root is $2-2,5 \mathrm{~cm}$ in diameter. The transverse root sections show a uniform rhytidome, made up of a single 
peridermis with 6 to 8 layers of almost tabulet phellem cells (Figure 2, H). The layers were formed by rows of thin-walled cells. The phelloderm was unstratified. Roots show 4-5 rings of collateral vascular bundles embedded in conjunctive parenchyma. Large idioblasts with numerous minute crystals of calcium oxalate are present in the conjunctive tissue (Figure 2, F).

In this species the strands of xylem and phloem are quite small, the phloem consisting of 3-4 sieve tubes only. The xylem strands contain 1-2 rows of 2-3 radially placed vessels. The fibres with small simple pits are few and shows a thick-walled (Figure 2, I).

- Macerated roots. The analysis of the material yielded the following constitutive elements:

a) Phellem cells. In cross-sections they were rectangular with thin-walled cells and measuring $50-80 \mu \mathrm{m}$ in length and $40 \mu \mathrm{m}$ in wide. In the superficial view they are polygonal, attaining a diameter of $50 \mu \mathrm{m}$ (Figure 2, H, G).

b) Conjunctive parenchyma. It showed polygonal cells. The average dimensions of parenchyma cells are $170 \mu \mathrm{m}$ in length and $50 \mu \mathrm{m}$ in wide (Figure 2, E).

c) Vessel. The vessels possessed alternate bordered pits with a simple perforation plate in transverse to slightly oblique end walls and measuring $100 \mu \mathrm{m}$ in length and $50 \mu \mathrm{m}$ in diameter (Figure 2, A, D).

d) Xileme fibers. They are scanty and measuring 250$300 \mu \mathrm{m}$ in length and $10-12 \mu \mathrm{m}$ in diameter (Figure 2, A, C).

e) Fibre-tracheid. Measuring $150 \mu \mathrm{m}$ in length and 10$12 \mu \mathrm{m}$ in diameter (Figure 2, B).

\section{Pfaffia paniculata}

The root is $3-4 \mathrm{~cm}$ in diameter. The transverse root sections show a uniform rhytidome, made up of a single peridermis with 12 to 14 layers of almost tabulet phellem cells. The layers were formed by rows of thick-walled cells (Figure 2, Q, R). The phelloderm was unstratified. Roots show 12-14 rings of collateral vascular bundles embedded in conjunctive tissue. Large idioblasts with calcium oxalate crystals of different shapes are present in the conjunctive tissue; i.e., octahedral prisms, rectangular prisms and octahedrons (Figure 2, O, P).

In this species the strands of xylem and phloem are large, the phloem consisting of 6-8 sieve tubes. The xylem strands contain 1-4 rows of 4-6 radially placed vessels. Fibbers with small simple pits are abundant (Figure 2, S).

- Macerated roots. The analysis of the material yielded the following constitutive elements: a) Phellem cells. In cross-sections they were rectangular with thick-walled cells and measuring $75 \mu \mathrm{m}$ in length and $45 \mu \mathrm{m}$ in wide. In the superficial view they are polygonal, attaining a diameter of 45-50 $\mu \mathrm{m}$ (Figure 2, Q, R).

b) Conjunctive parenchyma. It showed elongated longitudinal cells. The average dimensions of parenchyma cells are $100 \mu \mathrm{m}$ in length and $50 \mu \mathrm{m}$ in wide (Figure 2, N).

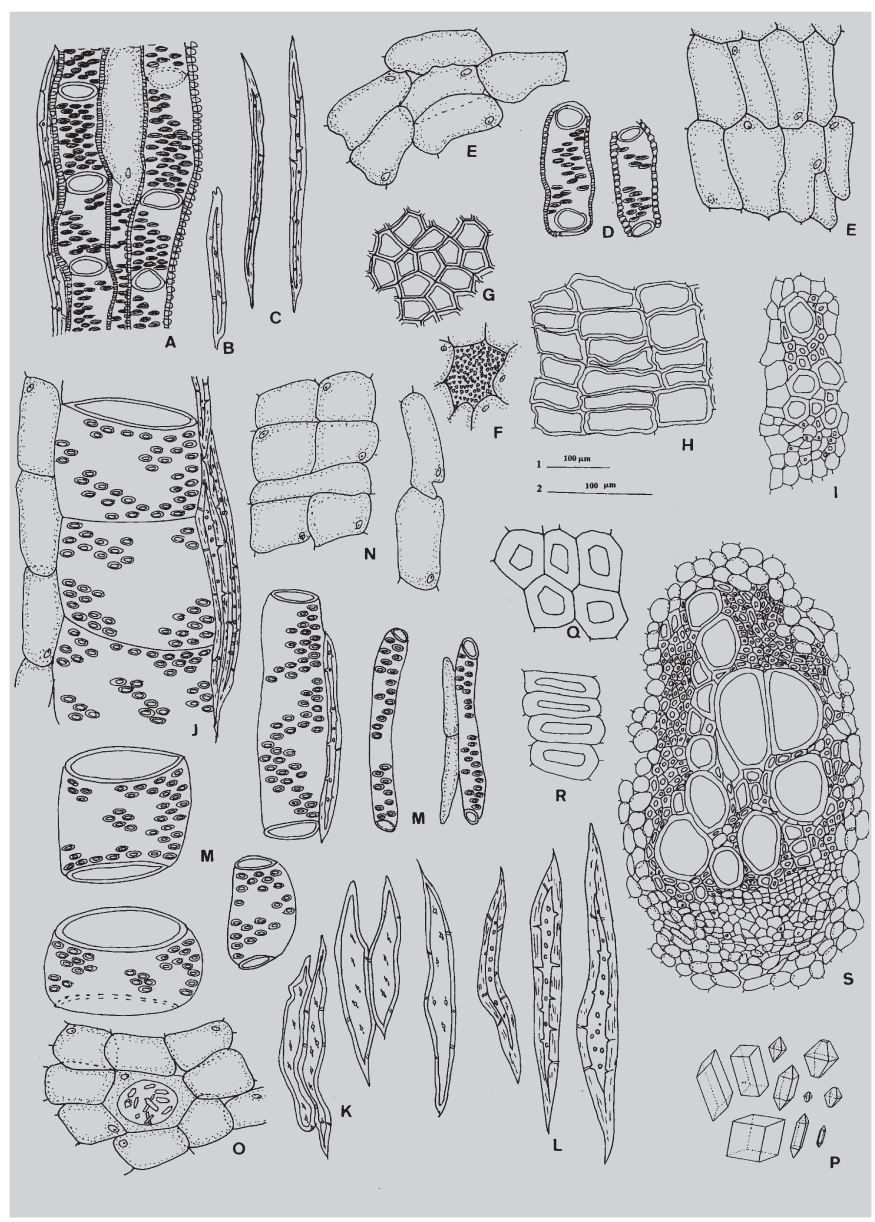

FIGURE 2 - A-S: Non-common characteristics. A-I Pfaffia glomerata (Spreng) Pedersen; A: Xylem, longitudinal view; B: fibre-tracheid; C: fibres; D: vessel; $\mathrm{E}$ : conjunctive parenchyma; $\mathrm{F}$ : idioblasts with numerous minute crystals calcium oxalate; G: phellem in superficial view; H: phellem in cross section; I: collateral vascular bundles; J-S: Pfaffia paniculata (Mart.) O. Kuntze J: Xylem, longitudinal view; K: fibre-tracheid; L: fibres; M: vessel; $\mathrm{N}$ : conjunctive parenchyma; O: idioblasts with calcium oxalate crystals, octahedric, rectangular prisms and octahedrons; P: crystals; Q: phellem in superficial view; R: phellem in cross section; S: collateral vascular bundles 
c) Vessel. The vessels possessed alternate bordered pits with a simple perforation plate in transverse to slightly oblique end walls. The mean vessel member length and diameter are $40 \mu \mathrm{m}$ and $120 \mu \mathrm{m}$ respectively and others vessels measuring $165 \mu \mathrm{m}$ in length and $65 \mu \mathrm{m}$ in diameter (Figure 2, J, M).

d) Xileme fibres. They are very abundant, thickwalled, measuring $350 \mu \mathrm{m}$ in length and $25 \mu \mathrm{m}$ in diameter (Figure 2, J, L).

e) Fibre-tracheid. Thin-walled, they measured $200 \mu \mathrm{m}$ in length and $35 \mu \mathrm{m}$ in diameter (Figure 2, K).

The examined species differ in morphologic and anatomic features, as shown in Table I.

\section{Chemical and biological data}

Ethanolic extracts from $P$. glomerata and $P$. paniculata present different TLC profiles at the chromatographic conditions used. It was possible to identify the presence of ecdysterone in $P$. glomerata extract as already described in the literature (Shiobara et al., 1993a), but not in P. paniculata extract. It seems that this compound could be a good marker for the differentiation of both species. The other substances used in TLC were not good references as both species presented spots with similar Rf and color.

Regarding to biological assays, ethanolic extract from $P$. glomerata did not present neither antiproliferative, antiviral, antifungal nor MAO inhibitory activities. Nevertheless, it is interesting to note that its cytotoxicity is very low $\left(\mathrm{IC}_{50}>2,000 \mu \mathrm{g} / \mathrm{mL}\right)$.

From results reported here, we could observe that roots from $P$. glomerata and $P$. paniculata differ in their botanical parameters and TLC profile, being both characteristics useful for avoiding adulterations.

Regarding results obtained in biological assays, $P$. glomerata showed to be inactive in all the activities tested, such as antifungal, antiviral, antitumoural and MAO inhibition. Interesting enough, our studies demonstrated that this species is not cytotoxic.

Finally, careful evaluation of the available scientific data for Pfaffia species allow us to consider that more studies are necessary to provide chemical, pharmacolo-

TABLE I - Non-common features of Pfaffia glomerata and Pfaffia paniculata

Pfaffia glomerata Pfaffia paniculata

\section{Exomorphology}

The root is $2-2.5 \mathrm{~cm}$ in diameter

\section{Anatomy}

A single peridermis with 6 to 8 layers, thin-walled cells. 4-5 rings of small collateral vascular bundles embedded in conjunctive tissue.

- The xylem strands contain 1-2 rows of 2-4 radially placed vessels.

\section{Macerate}

- Phellem cells: Measuring 50-80 $\mu \mathrm{m}$ in length and $40 \mu \mathrm{m}$ in wide.

- Conjunctive parenchyma: Cell size $100 \mu \mathrm{m}$ in length and $50 \mu \mathrm{m}$ in wide.

Large idioblasts with numerous minute crystals of calcium oxalate.

- Vessel: $100 \mu \mathrm{m}$ in length and $100 \mu \mathrm{m}$ in diameter.

- Fibres: 250-300 $\mu \mathrm{m}$ in length and 10-12 $\mu \mathrm{m}$ in diameter.

- Fibre-tracheid: $150-300 \mu \mathrm{m}$ in length and $10-12 \mu \mathrm{m}$ in diameter

\section{Exomorphology}

The root is $3-4 \mathrm{~cm}$ in diameter

\section{Anatomy}

A single peridermis with 12 to 14 layers, thick-walled cells.

- 12-14 rings of large collateral vascular bundles embedded in conjunctive tissue.

- The xylem strands contain 1-4 rows of 4-6 radially placed vessels.

\section{Macerate}

Phellem cells: Measuring $75 \mu \mathrm{m}$ in length and $45 \mu \mathrm{m}$ in wide.

Conjunctive parenchyma: Cell size $100 \mu \mathrm{m}$ in length and $50 \mu \mathrm{m}$ in wide.

Large idioblasts with calcium oxalate crystals, octahedric, rectangular prisms and octahedrons.

- Vessel: $40 \mu \mathrm{m}$ in length and $120 \mu \mathrm{m}$ in diameter; $165 \mu \mathrm{m}$ in length and $65 \mu \mathrm{m}$ in diameter

- Fibres: thick-walled, $350 \mu \mathrm{m}$ in length and $25 \mu \mathrm{m}$ in diameter.

- Fibre-traqueid: Thin-walled, $200 \mu \mathrm{m}$ in length and $35 \mu \mathrm{m}$ in diameter. 
gical and technological basis for their therapeutic use. This is really important taking into account that several phytopharmaceutical preparations containing $P$. glomerata or P. paniculata are available in Brazilian market without definitive proofs of their efficacy and safety. Even if eventual claim for traditional use of these preparations is considered, there are not consistent ethnobotanic reports on $P$. glomerata and P. paniculata. Furthermore, it is necessary to point out that the quality criteria for both - raw materials and phytopharmaceutical preparations - are still not well established. This study intends to have contributed specially toward the latest question.

\section{RESUMO}

\section{Características botânicas (morfológicas, micrográficas), químicas e farmacológicas de espécies de Pfaffia (Amaranthaceae) nativas do Sul} do Brasil

Alguns parâmetros são apresentados para o controle de qualidade de raizes de Pfaffia glomerata $e$ Pfaffia paniculata, utilizando suas características botânicas e químicas. Realizou-se, também, um screening farmacológico de $\mathrm{P}$. glomerata direcionado às atividades relacionadas com seu uso como "tônico". O extrato etanólico das raizes de $\mathrm{P}$. glomerata não apresentou atividade antiviral, antiproliferativa, antifúngica ou atividade inibitória de monoaminoxidases. A avaliação da citotoxicidade determinou que a $\mathrm{CI}_{50}$ é $>2.000 \mu \mathrm{g} / \mathrm{mL}$. As principais características morfológicas e micrográficas das raizes de P. glomerata e P. paniculata descritas permitem auxiliar na sua identificação segura.

UNITERMOS: Pfaffia glomerata. Pfaffia paniculata. Ginseng brasileiro. Micrografia. Controle de qualidade.

\section{ACKNOWLEDGMENTS}

We are grateful to Ílio Montanari from CPQBA (Universidade de Campinas, UNICAMP, São Paulo) for furnishing cultivated material. Micrographic study was supported by U.N.R. (Universidad Nacional de Rosario). G.G. and S.M.K.R. thank CNPq (Brazil) for fellowships and grant. Part of this work was supported by grants from SAZ (Agencia de Promociones Científicas y Tecnológicas de la Argentina PICT99 \# 06-06454) and OEA, Proyecto Aprovechamiento de la Flora Regional; and it is part of the collaborative research within the "Bioactive Natural Products and their Applications" nucleus from the
Association of Universities of the Montevideo Group (AUGM). Collaboration from the Iberoamerican Program of Science and Technology for the Development (CYTED) (Project X.7) is gratefully acknowledged.

\section{REFERENCES}

ARLETTI, R.; BENELLI, A.; CAVAZZUTI, E.; SCARPETTA, G.; BERTOLINI, A. Stimulating property of Turnera diffusa and Pfaffia paniculata extracts on the sexual behavior of male rats. Psychopharmacology, v. 143, p. 15-19, 1999.

BOODLE, I. A. A method of macerating fibres. Royal Botanical Garden, Kew Bulletin Miscellanous Informative, v. 4, p. 108-110, 1916.

DE-PARIS, F.; SALGUEIRO, J.; MOREIRA ROSA, R.; GOSMANN, G.; IZQUIERDO, I.; RATES, S. M. K. Análise cromatográfica e atividade depressora central de produtos vegetais comercializados como Pfaffia paniculatta Mart. Kuntze (Amaranthaceae) no RS (Brasil). JORNADA DE JÓVENES INVESTIGADORES GRUPO DE MONTEVIDEO, 6., Santa Fe, 1998. Resúmenes. Santa Fé: Universidade Nacional del Litoral, 1998a.p. 119.

DE-PARIS, F.; QUEVEDO, J., SALGUEIRO, J.; RATES, S. M. K.; IZQUIERDO, I. Potencial atividade depressora do extrato de Pfaffia glomerata sobre o sistema nervoso central. Rev. Med. ATM 1998, v. 18, p. 12-17, 1998b.

DE-PARIS, F., NEVES, G.; SALGUEIRO, J. B.; QUEVEDO, J.; IZQUIERDO, I.; RATES, S. M. K. Psychopharmalogical screening of Pfaffia glomerata Spreng. (Amaranthaceae) in rodents. $J$. Ethnopharmacol., v. 73, p. 261-269, 2000.

DIZEO DE STRITTMATER, C. Modificación de una coloración Safranina Fast green. Bol. Soc. Arg. Botánica, v. 18, p. 121-122, 1979.

FERESIN, G. E.; TAPIA, A.; LÓPEZ, S. N.; ZACCHINO, S. A. Antimicrobial activity of plants used in traditional medicine of San Juan province, Argentina. $J$. Ethopharmacol., v. 78, p. 103-107, 2001.

GNERRE, C.; VON POSER, G. L.; FERRAZ, A.; VIANA, A. F.; TESTA, B.; RATES, S. M. K. Monoamine oxidase inhibitory activity of some Hypericum species native to South Brazil. Planta Med., v. 53, p. 1273-1279, 2001. 
LIKHITWITAYAWUID, K.; ANGERHOFER, C. K.; CORDELL, G. A.; PEZZUTO, J. M.; RUANGRUNGSI, N. Cytotoxic and antimalarial bisbenzylisoquinoline alkaloids from Stephania erecta. J. Nat. Prod., v. 56, p. 30-38, 1993.

MAZZANTI, G.; BRAGHIROLLI, L. Analgesic and antiinflammatory action of Pfaffia paniculata (Martius) Kuntze. Phytother. Res., v. 8, p. 413-416, 1994.

METCALFE, C.; CHALK, L. Anatomy of the Dicotyledons. Oxford: Clarendon, 1957. v. 1, p. 1067-1074.

MITSCHER, L.; LEU, R.; BATHALA, M.; WU, W.; BEAL, J. Antimicrobial agents from higher plants. I. Introduction, rationale and methodology. Lloydia, v. 35, p. $157-166,1972$.

NAKAI, S.; TAKAGI, N.; MIICHI, H.; HAYASHI, S.; NISHIMOTO, N.; TAKEMOTO, T.; KIZU, H. Pfaffosides and nortriterpenoid saponins from Pfaffia paniculata. Phytochemistry, v. 23, p. 1703-1705, 1984.

NISHIMOTO, N.; NAKAI, S.; TAKAGI, N.; HAYASHI, S.; TAKEMOTO, T.; ODASHIMA, S.; KIZU, H.; WADA, Y. Pfaffosides and nortriterpenoid saponins from Pfaffia paniculata. Phytochemistry, v. 23, p. 139-142, 1984.

NISHIMOTO, N.; SHIOBARA, Y.; INOUE, S-S.; FUJINO, M.; TAKEMOTO, T.; YEOH, C. L.; OLIVEIRA, F.; AKISUE, G.; AKISUE, M. K.; HASHIMOTO, G. Three ecdysteroid glycosides from Pfaffia iresinoides. Phytochemistry, v. 27, p. 1665-1668, 1988.

OLIVEIRA, F. Pfaffia paniculata (Martius) KuntzeBrazilian Ginseng. Rev. Bras. Farmacognosia, v. 1, p. 8692, 1986.

SANTOS, R. I.; SANTOS, M. A.; SCHENKEL, E. P. Análise cromatográfica de amostras comercializadas como Panax ginseng e Pfaffia paniculata. Cad. Farm., Porto Alegre, v. 3, p. 59-65, 1987.

SHIOBARA, Y.; INOUE, S-S.; KATO, K.; NISHIGUCHI, Y.; OISHI, Y.; NISHIMOTO, N.; OLIVEIRA, F.; AKISUE, G.; AKISUE, M. K.; HASHIMOTO, G. A nortriterpenoid, triterpenoids and ecdysteroids from Pfaffia glomerata. Phytochemistry, v. 32, p. 1527-1530, 1993a.
SHIOBARA, Y.; INOUE, S-S.; KATO, K.; NISHIGUCHI, Y.; NISHIMOTO, N.; OLIVEIRA, F.; AKISUE, G.; AKISUE, M. K.; HASHIMOTO, G. Pfaffane-type nortriterpenoids from Pfaffia pulverulenta. Phytochemistry, v. 33, p. 897-899, 1993b.

SIMÕES, C. M. O.; FALKENBERGER, M.; AULER MENTZ, L.; SCHENKEL, E. P.; AMOROS, M.; GIRRE, L. Antiviral activity of South Brazilian medicinal plant extracts. Phytomedicine, v.6, p. 205-214, 1999.

TAKEMOTO, T.; NISHIMOTO, N.; NAKAI, S.; TAKAGI, N.; HAYASHI, S.; ODASHIMA, S.; WADA, Y. Pfaffic acid, a novel nortriterpene from Pfaffia paniculata Kuntze. Tetrahedron Lett., v. 24, p. 1057-60, 1983.

TANIGUCHI, S. F.; BERSANI-AMADO, C. A.; SUDO, L. S.; ASSEF, S. M. C.; OGA, S. Effect of Pfaffia iresinoides on the experimental inflammatory process in rats. Phytother. Res., v. 11, p. 568-571, 1997.

VASCONCELOS, J. M. O. Estudo taxonômico sobre Amaranthaceae no RS, Brasil. Porto Alegre, 1982. 151 p. [Dissertação de Mestrado. Curso de Botânica, Universidade Federal do Rio Grande do Sul].

ZACCHINO, S.; SANTECCHIA, C.; LÓPEZ, S.; GATTUSO, S.; MUÑOZ, J.; CRUAÑES, A.; VIVOT, E.; CRUAÑES, J.; SALINAS, A.; RUIZ, R.; RUIZ, S. In vitro antifungal evaluation and studies on mode of action of eight selected species from the Argentina flora. Phytomedicine, v. 5, p. 389-395, 1998.

ZACCHINO, S.; LÓPEZ, S.; PEZZENATI, G.; FURLAN, R.; SANTECCHIA, C.; MUÑOZ, L.; GIANNINI, F.; RODRÍGUEZ, A.; ENRIZ, R. In vitro evaluation of antifungal properties of phenylpropanoids and related compounds acting against dermatophytes. J. Nat. Prod., v. 62 , p. 1353-1357, 1999.

Recebido para publicação em 20 de novembro de 2002. 